\title{
Effect of Basicity on Electroreduction with Controlled Oxygen Flow of Molten Slag Containing FeO
}

\author{
Yunming Gao ${ }^{1}$ Chao Duan ${ }^{1} \cdot$ Yingbin Yang $^{1} \cdot$ Dong Ruan $^{1}$ - Chuanghuang Yang $^{1}$. \\ Chuan Hong ${ }^{1}$
}

Published online: 26 October 2015

(C) The Minerals, Metals \& Materials Society (TMS) 2015

\begin{abstract}
This paper reports on electroreduction with controlled oxygen flow (COF) for extraction of iron along with oxygen by-product from molten slags containing iron oxide at $1723 \mathrm{~K}$. An electrolytic cell with COF was constructed by an iridium wire cathode and a porous platinum anode sintered on a one-end-closed magnesia-stabilized zirconia-based solid electrolyte tube. Effect of basicity of $\mathrm{SiO}_{2}-\mathrm{CaO}-\mathrm{Al}_{2} \mathrm{O}_{3}-\mathrm{MgO}-\mathrm{FeO}$ slag on electroreduction behavior of $\mathrm{FeO}$ was investigated by means of the linear sweep and the potentiostatic electrolysis. The possibility of the zirconia membrane as conductive noncorrosive anode material was also discussed. The results indicate that both cathode alloying and increasing slag basicity are helpful to the $\mathrm{FeO}$ electrolytic reduction in the molten slag. With the iridium wire as a cathode and an applied voltage at $2.5 \mathrm{~V}$, higher slag basicity results in higher electrolysis rate and higher reduction ratio of the $\mathrm{FeO}$; however, silicon is also precipitated during electrolysis. The applied voltage can cause the increased porosity in the zirconia membrane. The corrosion of the molten slag to the zirconia membrane during electrolysis is evidently aggravated when the slag basicity reaches 0.8 . In order to minimize the corrosion of the molten slag to the zirconia membrane during electrolysis, the slag basicity of 0.6 is relatively advisable for extraction of iron under conditions of experimentation.
\end{abstract}

The contributing editor for this article was U. Pal.

Yunming Gao

gaoyunming@wust.edu.cn

$1 \quad$ Key Laboratory for Ferrous Metallurgy and Resources Utilization of Ministry of Education, Wuhan University of Science and Technology, Wuhan 430081, China
Keywords Electroreduction - Molten slag containing $\mathrm{FeO} \cdot$ Basicity $\cdot$ Controlled oxygen flow $\cdot$ Zirconia-based solid electrolyte $\cdot$ Corrosion

\section{Introduction}

The iron and steel metallurgy industry is one of key emission sources of greenhouse gas $\mathrm{CO}_{2}[1,2]$. Production of metallic iron from molten slag containing iron oxide through direct electrolysis using inert electrode is an alternative compact process route of ironmaking to eliminate $\mathrm{CO}_{2}$ emissions [38]. However, it causes such problems as difficulty in the selection of candidate anode materials [4-6], low efficiency of electrolysis (to $30 \%$ ) [7], the dissolution of the anodic gases in the electrolyte, and so on. These problems can be theoretically avoided using an oxide-ion-conducting membrane (such as zirconia-based solid electrolyte) which separates the anode and the cathode in the molten slag. The membrane with only oxygen ions' strong permselectivity is used as a medium guiding a directional oxygen flow, and the oxygen ions from the molten slag are transferred through the membrane by applying an external voltage between the two electrodes. The membrane not only prevents adverse impact of the substances involved in anode reaction on cathode reaction, but also blocks passage of electrons and other nonoxygen ions, so as to eliminate interference of leakage current or other non-oxygen ions from molten slag. It is obvious that the electroreduction rate of the iron oxide in the molten slag has a close relationship with the oxygen ionic current flowing through the membrane. The larger the oxygen ionic current, the faster the iron oxide reduces. Therefore, in essence, this new metallurgical method can be described as electroreduction with controlled oxygen flow (COF) [9]. Previously, Pal and his co-workers described it as the solid 
oxide membrane (SOM) process [10-15]. With similar principle and method, several investigators [10-17] have extracted the desired metals such as magnesium, titanium, and tantalum from their respective oxide-containing molten salt systems at a temperature not more than $1573 \mathrm{~K}$, and the production of some metals has proven to be promising in the laboratory or even at a pilot scale. However, little work has been done on extraction of metal from molten slag systems at higher temperatures [18]. One of the reasons may be attributed to the experimental difficulties associated with the operation of high-temperature electrochemical cells, which undergo problems with chemical stability of stabilized zirconia, electrodes, and cell container.

It is well known that the oxygen sensors containing zirconia-based solid electrolyte are utilized extensively throughout the steelmaking process, and several investigators have also used the zirconia probes to measure the activity of $\mathrm{FeO}_{x}$ within the slag phase [19-22]. From these applications, it can be guessed that zirconia-based solid electrolyte has a good slag corrosion resistance at high temperature. The use of stabilized zirconia membrane is important in electrolysis process with $\mathrm{COF}$, which not only guides a directional oxygen flow, but also provides a possible way to obtain conductive noncorrosive anode material. So far, several investigations $[14,16]$ have been performed on the stability of stabilized zirconia membrane in the molten salt systems during SOM electrolysis. However, no similar work has been done in the molten slag at higher temperatures.

Recent studies by Sadoway [3, 4] and Gao [18] et al. suggest that $\mathrm{SiO}_{2}-\mathrm{CaO}-\mathrm{MgO}-\mathrm{Al}_{2} \mathrm{O}_{3}$ slag system is hopefully used as potential media for extraction of electrolytic iron. In this work, for easy exploration of the law of electroreduction with COF, an electrolytic cell was constructed by an iridium wire cathode and a porous platinum anode sintered on a one-end-closed magnesia-stabilized zirconia-based solid electrolyte (MSZ) tube. Effect of basicity of $\mathrm{SiO}_{2}-\mathrm{CaO}-\mathrm{Al}_{2} \mathrm{O}_{3}-\mathrm{MgO}-\mathrm{FeO}$ slag on electroreduction behavior of $\mathrm{FeO}$ was investigated with the electrolytic cell by means of linear sweep and potentiostatic electrolysis at $1723 \mathrm{~K}$, and the corrosion of the molten slag to the zirconia membrane was also examined during electrolysis. This work will act as a foundation for investigations of electroreduction with $\mathrm{COF}$ for extraction of metal along with oxygen by-product from molten oxide systems at high temperature.

\section{Experimental}

\section{Preparation of Slags}

Mother slags were prepared from analytical reagents (ARs) including $\mathrm{CaCO}_{3}, \mathrm{SiO}_{2}, \mathrm{Al}_{2} \mathrm{O}_{3}$, and $\mathrm{MgO}$ calcined at
Table 1 Chemical composition of the slag samples

\begin{tabular}{|c|c|c|c|c|c|c|}
\hline \multirow[t]{2}{*}{ No. } & \multicolumn{5}{|c|}{ Chemical composition (wt\%) } & \multirow[t]{2}{*}{$R$} \\
\hline & $\mathrm{CaO}$ & $\mathrm{SiO}_{2}$ & $\mathrm{Al}_{2} \mathrm{O}_{3}$ & $\mathrm{MgO}$ & $\mathrm{FeO}$ & \\
\hline $\mathrm{A} 1$ & 19.3 & 48.2 & 8.1 & 14.4 & 10 & 0.4 \\
\hline $\mathrm{A} 2$ & 28.0 & 47.0 & 9.0 & 16.0 & 0 & 0.6 \\
\hline A3 & 25.2 & 42.3 & 8.1 & 14.4 & 10 & 0.6 \\
\hline A4 & 30.0 & 37.5 & 8.1 & 14.4 & 10 & 0.8 \\
\hline
\end{tabular}

$1223 \mathrm{~K}$ for $6 \mathrm{~h}$ in a muffle furnace, and $\mathrm{FeO}$ was directly added into the mother slags in the form of ferrous oxalate (AR) powder [23]. Assumed percentage of slag composition is shown in Table 1. The slags with low basicity $R=\mathrm{CaO} / \mathrm{SiO}_{2} \mathrm{wt} \%$ were investigated in order to prevent potential dissolution of the zirconia. The above-mixed powders were melted in an alumina crucible with highpurity $99 \mathrm{wt} \% \mathrm{Al}_{2} \mathrm{O}_{3}$ at $1673 \mathrm{~K}$ for $1 \mathrm{~h}$ under the $\mathrm{Ar}$ gas purified by two-stage successive treatment of copper wires and magnesium chips at $853 \mathrm{~K}$. The crucible containing slag melt was removed rapidly from the furnace and then quenched in water. The crucible was shattered after it was moved out from the water. The pre-melted slag was collected and placed in silica gel-contained desiccator ready for use.

\section{Construction of Electrolytic Cell}

The electrolytic cell consists of a one-end-closed MSZ tube and two electrodes, and the schematic structure of the electrolytic cell is shown in Fig. 1. The MSZ tube also functions as an oxygen ionic membrane between cathode and anode, and the sizes of MSZ tube are $11.5 \mathrm{~mm}$ ID, $14.0 \mathrm{~mm}$ OD, and $58.0 \mathrm{~mm}$ length. The outer surface of MSZ tube in the closed end was uniformly coated with platinum paste (supplied by Sino-Platinum Metals Co., Ltd, China) using a self-made feather brush. After the coating on the MSZ tube was dried in the shade, the MSZ tube was placed in the muffle furnace with open door to sinter for $30 \mathrm{~min}$ at $1173 \mathrm{~K}$. A porous platinum anode $\left(5.28 \mathrm{~cm}^{2}\right.$ in area) with good conductivity, uniform covering, and strong



Fig. 1 Schematic of the electrolytic cell 
adhesion was obtained. A Pt wire (0.5 $\mathrm{mm}$ in diameter) was connected to the porous platinum anode and served as the current lead. Approx. $3.7 \mathrm{~g}$ pre-melted slag was loaded inside MSZ tube for each experiment. An iridium wire $(0.5 \mathrm{~mm}$ in diameter, $30 \mathrm{~mm}$ in length, purity at $99.95 \mathrm{wt} \%$ ) served as the cathode. Another end of the iridium wire was connected to a $\mathrm{Pt}$ wire $(0.5 \mathrm{~mm}$ in diameter) which served as the current lead. The cell with $\mathrm{COF}$ constructed is expressed as follows: $\mathrm{Ir},(\mathrm{FeO})_{\text {slag }}$ I MSZ I O $\mathrm{O}_{2}$ (air), Pt.

\section{Experimental Methods}

For the convenience of operation, the MSZ tube was extended with a long corundum tube $(15 \mathrm{~mm}$ ID, $80 \mathrm{~mm}$ Length) by high-temperature cement. The electrolytic cell unit was vertically placed to the constant-temperature area in the vertical tube furnace heated by $\mathrm{MoSi}_{2}$ elements. The purified dry argon was introduced into the furnace tube and the MSZ tube at a flow rate of 400 and $40 \mathrm{~mL} / \mathrm{min}$, respectively. The furnace was programmed to heat at the rate of $5 \mathrm{~K} / \mathrm{min}$ to $1723 \mathrm{~K}$. A CHI1140A type electrochemical workstation (produced by Shanghai $\mathrm{CH}$ Instruments Co., Ltd, China) was connected to the electrode leads. After an equilibration time of approximately $15 \mathrm{~min}$ at $1723 \mathrm{~K}$, the iridium tip cathode dropped slowly, the exact contact point of electrode and molten slag surface was determined by observing a sudden change of the opencircuit voltage versus time recorded in real time. Then the iridium tip cathode was slowly inserted in the molten slag to a depth of 7-8 $\mathrm{mm}$. The argon in the furnace tube was switched to the air with a flow rate still at $400 \mathrm{~mL} / \mathrm{min}$, and it was visible that the open-circuit voltage changed with time in the process of gas switching. After the opencircuit voltage was stabilized, a linear sweep voltammetry was performed. Its initial sweeping voltage was the measured open-circuit potential, final voltage was $4 \mathrm{~V}$, and sweeping rate was $0.01 \mathrm{~V} / \mathrm{s}$. The variation curve of current with sweeping voltage was recorded automatically.
Finally, potentiostatic electrolysis was conducted, while the voltage was applied based upon the linear sweep curve, and the current versus time curve was recorded in real time by the electrochemical workstation.

The experiment ceased in the case of current slump or minor variation of current during potentiostatic electrolysis. The furnace was cooled down to room temperature. The cells were cut open, and photos of all samples were taken directly with digital camera. The residues were examined by SEM (Nova 400 Nano) and EDS (INCAIE 350 Penta FET X-3). It was not convenient to make further detection on the electroreduction effect of the $\mathrm{FeO}$ with any other technique due to small slag amount used in this work.

\section{Results and Discussion}

\section{Linear Sweep Curve}

Figure 2 shows current-voltage linear sweep curves of the slag with different basicities when the porous platinum anode on the outer surface of the MSZ tube was exposed to flowing air. The current through the cell can be found to increase steadily, indicating that it is possible to obtain a higher current density with applying a larger voltage since a diffusion-limited current is not observed. Figure $2 \mathrm{a}$ reveals that, for the slag not containing $\mathrm{FeO}$ (Blank slag $\mathrm{A} 2$ ), when the sweep voltage is $0-1.2 \mathrm{~V}$, the external current through the electrolytic cell is close to zero, indicating no electrolytic reaction in this range of voltage. However, when sweep voltage is more than $1.2 \mathrm{~V}$, the external current in the circuit surges with the sweep voltage, indicating electrolytic reduction of oxide in the slag started. The decomposition voltage is usually obtained in linear sweep curve by tangent method. As depicted in Fig. 2b, the decomposition voltage of a certain oxide in the molten slag can be determined to be about $1.2 \mathrm{~V}$ by extrapolation of straight line part of the current-voltage
Fig. 2 a Linear sweep curves of the slags with different basicities (sweep rate: $0.01 \mathrm{~V} /$ s); b enlarged voltage-current curves in initial sweep stage

curve to zero (so-called tangent method). The calculation of thermodynamics software FactSage [24] suggests that $\mathrm{SiO}_{2}$ can be reduced easily compared with other oxide in the molten slag. Therefore, it is considered that the decomposition voltage of $\mathrm{SiO}_{2}$ contained in the blank slag is about $1.2 \mathrm{~V}$. According to $\mathrm{Si}-\mathrm{Ir}$ phase diagram [25], however, sweeping interruption was caused at a sweep voltage of about $3.7 \mathrm{~V}$ by the $\mathrm{Ir}$ cathode fusing due to generation of Si-Ir alloy with low melting point.

For the slag containing $\mathrm{FeO}$, equilibrium of $\mathrm{Fe}^{2+}, \mathrm{Fe}^{3+}$, and physically dissolved oxygen is formed at high temperatures [26-28] according to reaction (1):

$4 \mathrm{Fe}^{3+}+2 \mathrm{O}^{2-}=4 \mathrm{Fe}^{2+}+\mathrm{O}_{2}$.

Minute $\mathrm{Fe}_{2} \mathrm{O}_{3}$ may be included in the cases of low slag basicity and low partial pressure of oxygen in an inert argon gas environment [29, 30].

At the stage of low sweep voltage, the difference among sweep curves of slag with different basicities seems to be minor, as shown in Fig. 2a. Taking the slag A3 with $R=0.6$ and $10 \mathrm{wt} \% \mathrm{FeO}$ as an example, one can observe enlarged current-voltage curve at the initial sweep stage in Fig. 2b. At first, the current increases with sweep voltage, and then it surges nearly in a straight line. Thus, the voltage (about $0.04 \mathrm{~V}$ ) corresponding to the starting point at the initial sweep stage is considered as the decomposition voltage of $\mathrm{Fe}_{2} \mathrm{O}_{3}$ contained in the molten slag. The diffusion-limited current for $\mathrm{Fe}^{3+} / \mathrm{Fe}^{2+}$ reduction can be observed, and the corresponding cell reaction can be described by reaction (2). The Gibbs free energy change for reaction (2) is given by Eq. (3).

$\left(\mathrm{Fe}_{2} \mathrm{O}_{3}\right)=2(\mathrm{FeO})+1 / 2 \mathrm{O}_{2}$

$\Delta G=\Delta G^{0}+R T \ln \left(\frac{a_{\mathrm{FeO}}^{2}}{a_{\mathrm{Fe}_{2} \mathrm{O}_{3}}} p_{\mathrm{O}_{2}}^{1 / 2}\right)$,

where $\Delta G$ is the Gibbs free energy change, $\mathrm{J} / \mathrm{mol} ; \Delta G^{0}$ is the standard Gibbs free energy change, and the value of $\Delta G^{0}$ can be obtained by thermodynamics software FactSage and $\Delta G^{0}=75,612 \mathrm{~J} / \mathrm{mol}$ at $1723 \mathrm{~K} ; R$ is the ideal gas constant, $8.314 \mathrm{~J} /(\mathrm{mol} \mathrm{K}) ; T$ is the absolute temperature, $T=1723 \mathrm{~K} ; a_{\mathrm{i}}$ is the activity of $\mathrm{i}$ species in molten slag, the standard states of $\mathrm{Fe}_{2} \mathrm{O}_{3}$ and $\mathrm{FeO}$ in molten slag were taken as pure liquid $\mathrm{FeO}$ and pure liquid $\mathrm{Fe}_{2} \mathrm{O}_{3}$, respectively; and $p_{\mathrm{O}_{2}}$ is the oxygen partial pressure in the reference electrode. In theory, $p_{\mathrm{O}_{2}}$ equals 0.21 since the reference electrode is in equilibrium with the air.

For a limiting case when the applied current approaches zero, Eq. (4) becomes valid.

$\Delta G=-n F E_{n}$,

where $n$ is the number of electrons exchanged in the reaction, $n=2 ; F$ is the Faraday constant, $F=96,500$
$\mathrm{C} / \mathrm{mol}$; and $E_{\mathrm{n}}$ is the Nernst voltage established between cathode and anode or the measured open-circuit voltage for the reversible cell. When the oxygen ionic transference number in the MSZ membrane equals 1 in an ideal case, the decomposition voltage of $\mathrm{Fe}_{2} \mathrm{O}_{3}$ contained in the slag, namely the minimum applied voltage, should equal $E_{\mathrm{n}}$ based on the thermodynamic viewpoint.

As an approximation, herein the decomposition voltage of $\mathrm{Fe}_{2} \mathrm{O}_{3}$ contained in the molten slag is about $0.04 \mathrm{~V}$ according to previous extrapolation. It is understandable that $E_{\mathrm{n}}$ is taken as $-0.04 \mathrm{~V}$ in Eq. (4) since reaction (2) cannot occur spontaneously. Equation (5) can be obtained by combining Eqs. (3) and (4):

$\ln \frac{a_{\mathrm{FeO}}^{2}}{a_{\mathrm{Fe}_{2} \mathrm{O}_{3}}}=-4.0$,

that is

$\frac{a_{\mathrm{FeO}}^{2}}{a_{\mathrm{Fe}_{2} \mathrm{O}_{3}}}=0.018$.

Considering that the peak current of $\mathrm{Fe}_{2} \mathrm{O}_{3}$ is very small in Fig. 2b, $\mathrm{Fe}_{2} \mathrm{O}_{3}$ concentration should be negligibly low. Thus the $a_{\mathrm{FeO}}$ can be estimated as 0.17 by FactSage at a given initial $\mathrm{FeO}$ content of $10 \mathrm{wt} \%$ in the molten slag when the $\mathrm{Fe}_{2} \mathrm{O}_{3}$ concentration is ignored. However, the obtained $a_{\mathrm{Fe}_{2} \mathrm{O}_{3}}$ value (=1.6) is found to be more than 1 according to Eq. (5a). This is obviously unreasonable. The reason why the $a_{\mathrm{Fe}_{2} \mathrm{O}_{3}}$ value is more than 1 remains unknown. It may be ascribed to inaccurate decomposition voltage of $\mathrm{Fe}_{2} \mathrm{O}_{3}$ which is caused by capacitive charging of the double layer and other irreversible factors during sweeping.

At a low peak voltage of $\mathrm{Fe}_{2} \mathrm{O}_{3}$, the current surges linearly with the increase of the sweep voltage again. By drawing the cross-point between reverse of the second straight line of current-voltage curve and the horizontal axis, the decomposition voltage of FeO in the slag is determined to be about $0.28 \mathrm{~V}$. The cell reaction is given by reaction (6). The Gibbs free energy change for reaction (6) is given by Eq. (7).

$(\mathrm{FeO})=\mathrm{Fe}($ alloy $)+1 / 2 \mathrm{O}_{2}$

$\Delta G=\Delta G^{0}+R T \ln \left(\frac{a_{\mathrm{Fe}}}{a_{\mathrm{FeO}}} p_{\mathrm{O}_{2}}^{1 / 2}\right)=-n E_{\mathrm{n}} F$,

where $a_{\mathrm{Fe}}$ is the activity of Fe species in alloy, and the standard state of Fe in alloy was taken as pure solid Fe. The $\Delta G^{0}$ for reaction (6) equals $155062.7 \mathrm{~J} / \mathrm{mol}$ at $1723 \mathrm{~K}$ according to the calculation of thermodynamics software FactSage. As mentioned earlier, the $a_{\mathrm{FeO}}$ can be estimated as 0.17 in the molten slag. If the precipitate Fe exists in the form of pure solid $\mathrm{Fe}$, the activity of $\mathrm{Fe}$ is considered to be unity. Correspondingly, the theoretical decomposition voltage corresponding to the $\mathrm{Fe}^{2+} / \mathrm{Fe}$ reaction can be calculated as $0.88 \mathrm{~V}$ by means of Eq. (7). 
From the opposite viewpoint, Eq. (8) can be obtained by substituting $E_{\mathrm{n}}=-0.28 \mathrm{~V}$ in Eq. (7) since reaction (6) cannot occur spontaneously, too.

$\frac{a_{\mathrm{Fe}}}{a_{\mathrm{FeO}}}=1.89 \times 10^{-3}$

Herein, the $\frac{a_{\mathrm{Fe}}}{a_{\mathrm{FeO}}}$ ratio is too low and $a_{\mathrm{Fe}}$ will equal $3.2 \times 10^{-4}$ if the value of $a_{\mathrm{FeO}}$ is taken as 0.17 according to theoretical calculation. Such a low $a_{\mathrm{Fe}}$ value suggests that the decomposition voltage of $\mathrm{FeO}$ obtained by the socalled tangent method seems to be not reliable. In fact, it is unlikely to reduce the $\mathrm{FeO}$ to $\mathrm{Fe}$ when the applied voltage is $0.28 \mathrm{~V}$. The decomposition voltage of $\mathrm{FeO}$ is lower than the peak voltage of $\mathrm{Fe}_{2} \mathrm{O}_{3}$ (about $0.4 \mathrm{~V}$ from Fig. 2b) corresponding to the $\mathrm{Fe}^{3+} / \mathrm{Fe}^{2+}$ reaction.

It can be noticed from Fig. $2 b$ that the $\mathrm{Fe}_{2} \mathrm{O}_{3}$ reduction reaction is followed by the $\mathrm{FeO}$ reduction. After reduction of the $\mathrm{Fe}_{2} \mathrm{O}_{3}$, the current does not decrease to a lower value, but increases linearly with the increase of the sweep voltage. This causes an inflection point of the current to appear, indicating that the $\mathrm{FeO}$ undergoes reduction. Hence, the decomposition voltage of $\mathrm{FeO}$ may be estimated at $0.70 \mathrm{~V}$ from the voltage corresponding to the inflection point of the current for the $\mathrm{FeO}$ reduction in Fig. $2 \mathrm{~b}$. Correspondingly, Eq. (9) can be obtained by substituting $E_{\mathrm{n}}=-0.70 \mathrm{~V}$ in Eq. (7).

$\frac{a_{\mathrm{Fe}}}{a_{\mathrm{FeO}}}=0.543$

Herein, $a_{\mathrm{Fe}}$ equals $9.3 \times 10^{-2}$ if the value of $a_{\mathrm{FeO}}$ is taken as 0.17 . The activity of Fe is less than 1, indicating that Fe forms alloy with the Ir cathode in reaction (6). It is practical that the decomposition voltage of $\mathrm{FeO}$ is estimated by the inflection point.

With further increase of sweep voltage, the third straight line appears on current-voltage curve, indicating the reduction of $\mathrm{SiO}_{2}$. The cell reaction is given by reaction (10):

$\left(\mathrm{SiO}_{2}\right)=\mathrm{Si}$ (alloy) $+\mathrm{O}_{2}$.

The decomposition voltage is determined to be about $1.3 \mathrm{~V}$ by the inflection point, which is close to that of the $\mathrm{SiO}_{2}$ in the blank slag (A2). According to $\mathrm{Si}-\mathrm{Ir}$ [25], Fe-Ir [31], and $\mathrm{Fe}-\mathrm{Si}$ [32] phase diagrams, iron and silicon as the cathode products can react with the Ir wire cathode to form alloy during the linear sweep electrolysis, and the activity value of iron or silicon as the cathode product is less than 1 . Thus, the measured decomposition voltages of $\mathrm{FeO}$ and $\mathrm{SiO}_{2}$ are less than the theoretical decomposition voltages under comparable conditions based on the air reference state and the activity values of iron and silicon defined as unity, respectively.

It is unexpectedly seen from Fig. $2 b$ that the decomposition voltages of $\mathrm{FeO}$ obtained by the inflection point do not evidently increase with increasing slag basicity, but they were close to each other at different slag basicities. It may be ascribed to the use of a crude method in the present work. Generally, the activity of basic FeO can be affected by the slag basicity based on the thermodynamic viewpoint [33]. With an increase of the slag basicity, the activity of basic FeO increases, leading to shifting the equilibrium for reaction (6) to the right. This suggests that higher slag basicity is helpful to the $\mathrm{FeO}$ electrolytic reduction. Furthermore, it can be observed from Fig. $2 b$ that the current increases with increasing slag basicity at the same sweep voltage.

It should be noted that measurement of the decomposition voltage, through either tangent method or the inflection point, is a crude way of assessing the minimum applied voltage for electrolysis. Some factors such as sweeping rate, overvoltage, and capacitive charging of the double layer make it difficult to exactly identify the decomposition voltage. In fact, the decomposition voltage does not have much practical significance as the cell is generally operated at much higher voltages.

\section{Electrolysis Current-Time Curves}

According to above linear sweep curves, in order to increase electrolysis rate, and considering the overvoltage loss in the electrodes and the $I R$ drop in the circuit during electrolysis, the applied voltage is selected as $2.5 \mathrm{~V}$ to investigate electroreduction behavior of the molten slag when the Ir wire is used as the cathode.

Figure 3 shows current-time curves of the slags containing $10 \mathrm{wt} \% \mathrm{FeO}$ with various basicities, the applied voltage at $2.5 \mathrm{~V}$, and the air as an anode atmosphere. Due to precipitates of large amount of silicon in a short time during electrolysis of the FeO-free blank slag (A2), the Ir electrode was damaged resulting in the interruption of

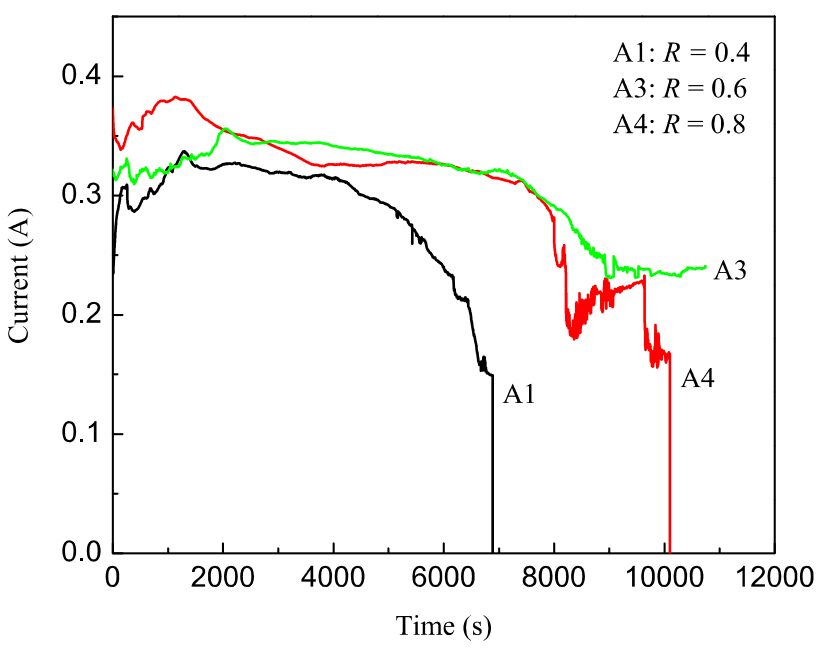

Fig. 3 Current-time curves of slags with different basicities 
electrolysis. For this reason, Fig. 3 does not show electrolysis curve of the blank slag (A2).

Based on the principle of electroreduction with $\mathrm{COF}$ [9], when the applied voltage between the anode and the cathode of the cell exceeds the decomposition voltage of $\mathrm{FeO}$ (or $\mathrm{SiO}_{2}$ ), $\mathrm{Fe}^{2+}$ (or $\mathrm{Si}^{4+}$, neglecting $\mathrm{Fe}^{3+}$ ) ions in the molten slag diffuse toward the iridium cathode whereby they are reduced. The cathodic reactions of $\mathrm{Fe}^{2+}$ and $\mathrm{Si}^{4+}$ can be described by reactions (11) and (12), respectively.

$$
\begin{aligned}
& \mathrm{Fe}^{2+}+2 \mathrm{e}=\mathrm{Fe} \text { (alloy) } \\
& \mathrm{Si}^{4+}+4 \mathrm{e}=\mathrm{Si} \text { (alloy) }
\end{aligned}
$$

or

$\mathrm{SiO}_{4}^{4-}+4 \mathrm{e}=\mathrm{Si}($ alloy $)+4 \mathrm{O}^{2-}$

At the same time, $\mathrm{O}^{2-}$ ions in the molten slag diffuse toward the interface of slag/MSZ tube and migrate through MSZ membrane to the platinum anode whereby they are oxidized to oxygen molecules escaping into the air. The anodic reaction is given by reaction (13):

$2 \mathrm{O}^{2-}=\mathrm{O}_{2}+4 \mathrm{e}$.

It is seen from Fig. 3 that, under the condition of the same initial content of the $\mathrm{FeO}$ in the slag, higher basicity generally imposes higher external current (assumed as ionic current) at the initial stage of electrolysis. Since the diffusion-limited current for $\mathrm{Fe}^{2+} / \mathrm{Fe}$ reduction is not observed in the current-voltage linear sweep curves (see Fig. 2), the increase of the external current is probably due to the increase of the conductivity of slag electrolyte with increasing slag basicity [34]. With a given initial basicity of the slag, the external current value tends to remain at high levels at the initial stage of electrolysis, indicating higher reduction rate of the $\mathrm{FeO}$. This is because the $\mathrm{FeO}$ concentration in the slag is high at the initial stage of electrolysis. It is well known that the $\mathrm{FeO}$ can reduce the melting point and increase the conductivity of the slag in ferrous metallurgy [33, 35]. The viscosity and the ohmic resistance of the slag with high $\mathrm{FeO}$ concentration are low, thus the ions in the molten slag diffuse fast and the current is large; besides, the alloy is formed by the reaction between the iron precipitated from the cathode and the Ir wire, and it can function as a new active cathode and accelerate electrolytic reaction. With further electrolytic reaction, the $\mathrm{FeO}$ concentration in the slag decreases gradually and the conductivity of the slag decreases (corresponding to an increase of the ohmic resistance of the cell), together with higher viscosity of the slag and slower diffusion rate of ions, leading to continual decreases of the external current. When the current drops to a lower value (residual current), the reduction reaction of the $\mathrm{FeO}$ contained in the slag was basically completed.

\section{Macroscopic Observations}

Figure 4 illustrates cut experimental samples after electrolytic reduction, where the blank slag $(R=0.6)$ and the slags containing $10 \mathrm{wt} \% \mathrm{FeO}$ with basicities $R=0.4,0.6$, and 0.8 were arranged, respectively, from the left to right. No noticeable changes were observed for the MSZ tubes used when seen with the naked eye. Besides, the electroreduction effect of the $\mathrm{FeO}$ in the slag could be roughly determined by contrast of the color of the residues.

It is well known that the original slag containing $10 \mathrm{wt} \%$ $\mathrm{FeO}$ is black, and the blank slag (A2) is clear and colorless. It is seen from the variation of color with physical slag samples as shown in Fig. 4 that the slag with basicity $R=0.8$ appears white after electrolytic reduction, nearly in the same color as the blank slag, suggesting that the slag reduction was in good effect; also, a pit is observed with the cut sample at the location of electrode, and the Ir electrode can be deduced to fuse due to alloying with the metal precipitated at the late stage of electrolysis. The slag with basicity $R=0.6$ is in light color after reduction, and deposit of metallic iron is visible surrounding the Ir cathode. Although the current is low for the slag with basicity $R=0.4$ during electrolysis, the Ir cathode was damaged due to precipitation of silicon on the Ir electrode, leading to only a short time of electrolysis. Although the color of slag becomes lighter than that of the initial slag, the color is much darker than the slag with relatively high basicity, from which it is inferred that the slag still contains high content of the $\mathrm{FeO}$, in other words, the reduction effect is less favorable.

\section{Microscopic Observations}

Only considering the reduction of the $\mathrm{FeO}$ in the molten slag during electrolysis, the reduction ratio of the $\mathrm{FeO}$ can be calculated according to Eq. (14):

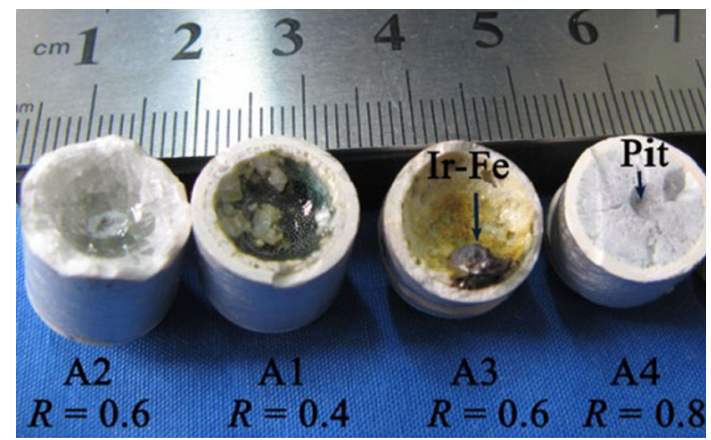

Fig. 4 Photo of the cut experimental samples after electrolysis of the slags with different basicities 
$\eta_{\mathrm{FeO}}=\frac{M_{\mathrm{FeO}} \times \int_{0}^{t} I_{\mathrm{ex}} d t}{m_{\mathrm{slag}} \times\left(\frac{\mathrm{FeO} \mathrm{wt}^{2}}{100}\right) \times n F} \times 100$,

where $\eta_{\mathrm{FeO}}$ is the reduction ratio of $\mathrm{FeO}$ in the slag, \%; $m_{\text {slag }}$ is the mass of the slag, $m_{\text {slag }}=3.7 \mathrm{~g} ; I_{\text {ex }}$ is the external current, A; $M_{\mathrm{FeO}}$ is the molar mass of $\mathrm{FeO}$, $M_{\mathrm{FeO}}=72 \mathrm{~g} / \mathrm{mol} ; \mathrm{FeO} \mathrm{wt} \%$ is the weight fraction of $\mathrm{FeO}$ in the slag, $\mathrm{FeO} w t \%=10$; and $t$ is the reduction time, $\mathrm{s}$.

In Eq. (14), the values of $\int_{0}^{t} I_{e x} d t$ are calculated by integrating the area under the measured current versus time plot in Fig. 3. Therefore, the curves of the FeO reduction ratio versus time can be obtained as shown in Fig. 5. The slags with basicities $R=0.6$ and $R=0.8$ have approximately the same reduction ratio, and the slag with basicity $R=0.4$ has the lowest value of the three calculated. However, all the final reduction ratios are found to be far above $100 \%$. This is obviously unreasonable. This should firstly be ascribed to the presence of the reduction of the $\mathrm{SiO}_{2}$ in the molten slag during electrolysis in this present work.

It is found from SEM observations and the EDS of electrolytic products after the experiment that the Ir wire electrode surely reacted with $\mathrm{Fe}$ and $\mathrm{Si}$ precipitated from electrolytic reduction with different basicities and the alloy was formed. Figure 6 and Table 2, respectively, show typical SEM image and EDS analytical result of the Ir wire electrode in the slag (A4) with basicity $R=0.8$ after electrolysis. Possible phases are also shown in Table 2. The Ir electrode is evidently divided into two parts. The EDS analysis indicates that the electrode has become $\mathrm{Fe}-\mathrm{Si}-\mathrm{Ir}$ alloy, and the bright part contains higher content of Ir. Under the conditions of this experiment, the alloy formed only by $\mathrm{Fe}-\mathrm{Ir}$ reaction is not likely to fuse the Ir electrode at $1723 \mathrm{~K}$ based on $\mathrm{Fe}-\mathrm{Ir}$ phase diagram [31]; however, when the alloy with low melting point is formed by $\mathrm{Si}-\mathrm{Ir}$ reaction [25], it leads to fusing of the Ir electrode and

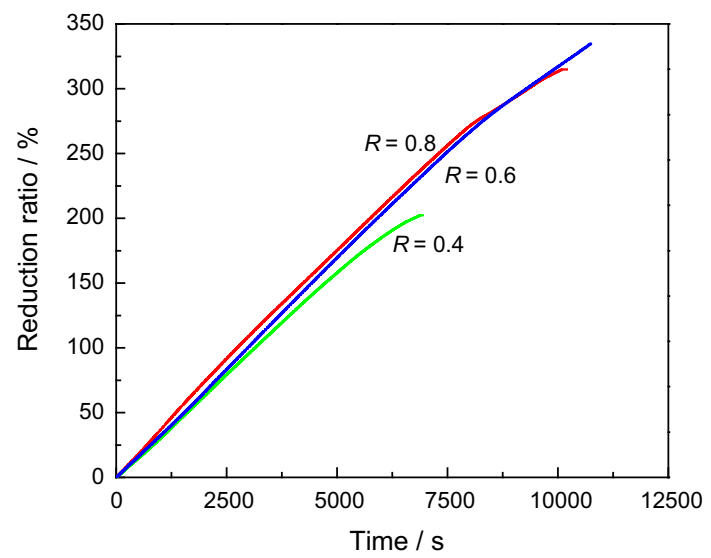

Fig. 5 Curves of the reduction ratio of $\mathrm{FeO}$ in the molten slags with different basicities

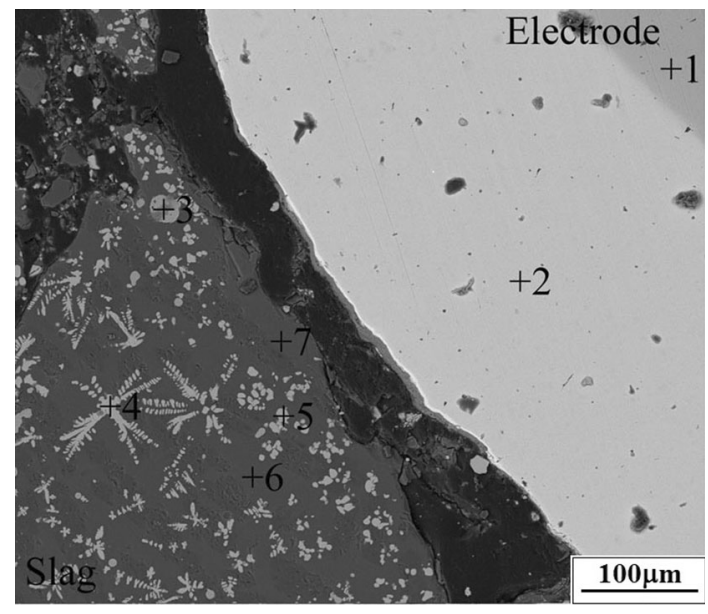

Fig. 6 SEM image of residue after electrolysis of slag (A4)

interruption of electrolysis, as shown in Fig. 3. The EDS analysis also indicates that no $\mathrm{ZrO}_{2}$ in the slag was reduced to $\mathrm{Zr}$. Besides, some ferrosilicon alloy beads can occasionally be found in the residue. Therefore, the reduction ratios shown in Fig. 5 are actually total reduction ratios of the $\mathrm{FeO}$ and the $\mathrm{SiO}_{2}$ in the molten slag. It is possible that the $\mathrm{SiO}_{2}$ in the molten slag had begun to reduce due to kinetic factors before the $\mathrm{FeO}$ reduced completely. The reduction of the $\mathrm{SiO}_{2}$ and the color variation of the slags with different basicities after electrolysis suggest that the diffusion rate in the slag may be slow due to lower $\mathrm{FeO}$ concentration at the late stage of electrolysis. Since the amount of $\mathrm{SiO}_{2}$ reduction could not exactly be determined after electrolysis, it is difficult to obtain exactly the reduction ratio of the $\mathrm{FeO}$ only from the current-time curves of the molten slag.

The electrolysis experiments in Fig. 3 have been compared to a static experiment in which a zirconia tube inside loaded the slag (A3) with basicity $R=0.6$ for $3 \mathrm{~h}$ without electrolysis. Figure 7 shows SEM images of the residue in these experiments. Both the slag penetration into the MSZ tube and the leaching of the stabilizing agent into the slag can be observed in Fig. 7. The so-called cellular tissue emerges in large grains. The cellular tissue contains $\mathrm{Si}, \mathrm{Ca}$, and $\mathrm{Mg}$ besides $\mathrm{Zr}$ and $\mathrm{O}$ elements. The cellular tissue will induce a phase transformation of zirconia from the fully stabilized cubic or the partially stabilized tetragonal phase with large size into the monoclinic phase with small size. The phase transformation phenomenon in stabilized zirconia-based ceramics has also been studied by several investigators and may be considered as the most important cause of ceramics corrosion in the molten slag [36-38].

In addition, it can be found that the zirconia membranes with electrolysis exhibited increased porosity when compared to the static experiment with the same slag basicity $R=0.6$ without electrolysis, as shown in Fig. 7a and c. 
Table 2 Results of related EDS analysis in Fig. 6

\begin{tabular}{lllllllllll}
\hline Spot & \multicolumn{1}{l}{ Element $(\mathrm{wt} \%)$} & \multicolumn{1}{l}{ Possible phase } \\
\cline { 2 - 8 } & $\mathrm{Mg}$ & $\mathrm{Al}$ & $\mathrm{Si}$ & $\mathrm{Ca}$ & $\mathrm{Fe}$ & $\mathrm{O}$ & $\mathrm{Zr}$ & $\mathrm{Ir}$ & \\
\hline 1 & - & - & 6.43 & - & 89.68 & - & - & 3.89 & $\mathrm{Si}-\mathrm{Fe}-\mathrm{Ir}$ alloy \\
2 & - & - & 7.16 & - & 61.62 & - & - & 31.22 & $\mathrm{Si}-\mathrm{Fe}-\mathrm{Ir}$ alloy \\
3 & - & - & 1.67 & - & 98.33 & - & - & - & $\mathrm{Si}-\mathrm{Fe}$ alloy bead \\
4 & - & - & - & 3.71 & - & 26.10 & 70.18 & - & $\mathrm{CaO}-\mathrm{ZrO}{ }_{2}$ \\
5 & 1.11 & - & - & 4.05 & - & 19.26 & 75.58 & - & $\mathrm{MgO}-\mathrm{CaO}-\mathrm{ZrO}_{2}$ \\
6 & 5.92 & - & 26.16 & 24.46 & - & 43.46 & - & - & $\mathrm{MgO}-\mathrm{CaO}-\mathrm{SiO}_{2}$ \\
7 & 3.99 & 6.93 & 23.78 & 21.04 & - & 44.27 & - & - & $\mathrm{MgO}-\mathrm{CaO}-\mathrm{SiO}_{2}-\mathrm{Al}_{2} \mathrm{O}_{3}$ \\
\hline
\end{tabular}
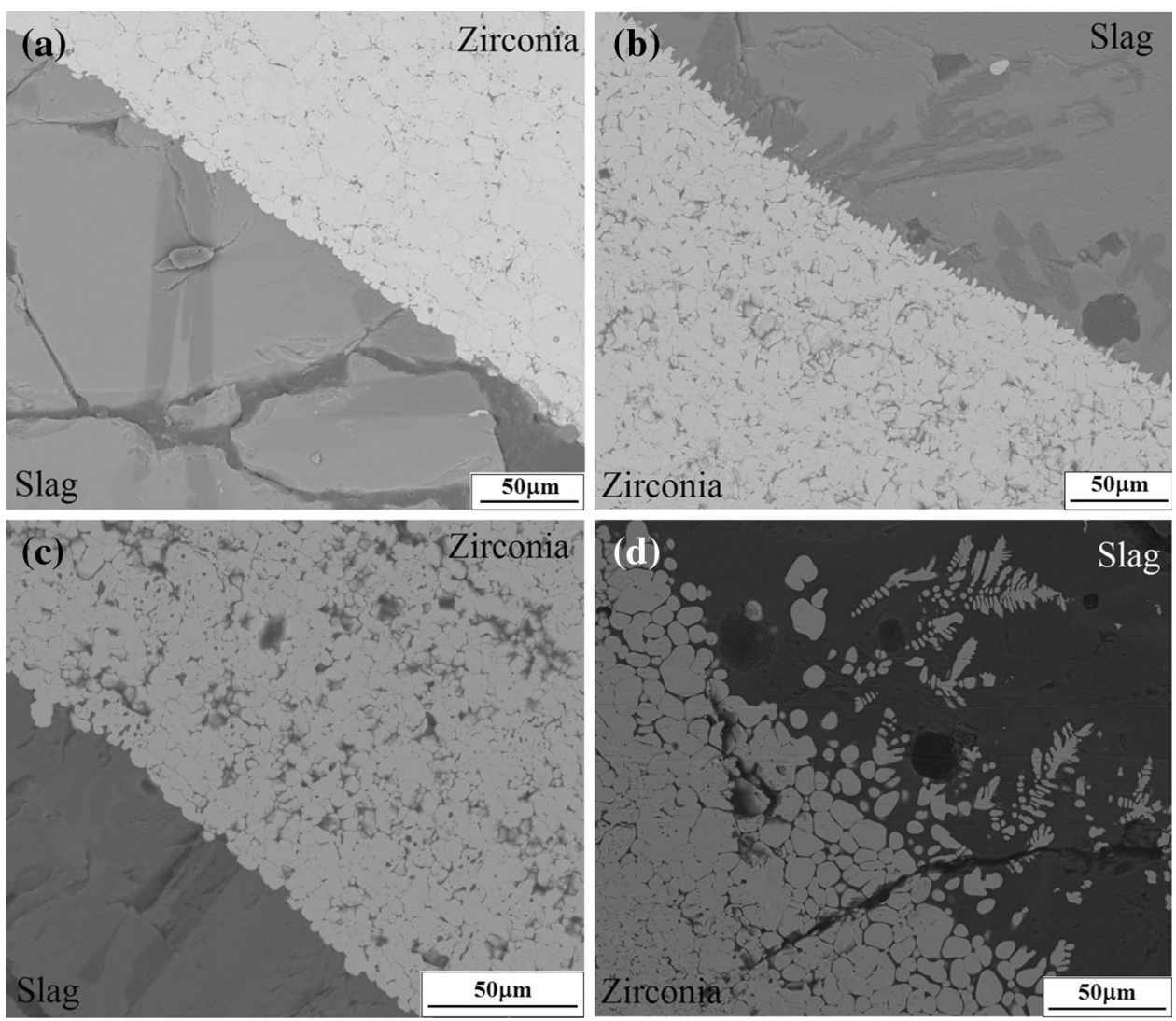

Fig. 7 SEM images of the interface between $\mathrm{ZrO}_{2}$ and slag with different basicities after electrolysis. a $\mathrm{ZrO}_{2}$ exposed to slag A3 (holding $3 \mathrm{~h}$ at $1723 \mathrm{~K}$ ) without electrolysis and with electrolysis in Fig. 3: b slag A1, $R=0.4$; c slag $\mathrm{A} 3, R=0.6$; and d slag $\mathrm{A} 4, R=0.8$
The increased porosity suggests the aggravation of corrosion of zirconia membrane by molten slag. In general, the corrosion of the molten slag to ceramics and refractory materials can evidently be aggravated due to high $\mathrm{FeO}$ content in ferrous metallurgy. The $\mathrm{FeO}$ content in the molten slag is not variable in the static experiment; however, it gradually decreases during electrolysis. So the increased porous region in the zirconia membrane during electrolysis is believed not to be related to the FeO content in the molten slag but to the applied voltage. Some studies [39-41] suggested that applying a voltage to porous refractory-liquid oxide system could change the interfacial characteristics of the liquid oxide penetration. The significant acceleration of the penetration of the slag is presumably caused by a decrease of interfacial tension at the slag-zirconia membrane interface when the applied voltage is $2.5 \mathrm{~V}$ in the present work. Thus the zirconia grain is surrounded by more slag. In this case, the interaction between the zirconia grain and the slag can cause the loose of the grains; besides, the $\mathrm{MgO}$ stabilizing agent becomes more prone to loss. The above two aspects are also the cause of the cellular tissue. When the decrease of the $\mathrm{MgO}$ content of the grain reaches a critical value due to the leaching of the stabilizing agent into the slag, the cubic or tetragonal phase transforms into the monoclinic phase. The phase transformation with an accompanied volume 
expansion results in disintegration of a large grain, which also causes further loose of the grains. Therefore, the total porosity in the zirconia membrane is increased under applying voltage. The high porosity can cause the molten slag to flow into the membrane and deplete the magnesia from the exposed surface of the membrane. However, noticeable phase transformation phenomenon in the zirconia grain is not observed and only the so-called cellular tissue can be observed in the present work. This also indicates that the corrosion of the molten slag to the zirconia membrane is limited to some extent.

It is also found that slag basicity has an impact on the corrosion of zirconia membrane by the molten slag. At a low slag basicity of 0.4 , the zirconia grains with an irregular shape with a serrated border can be observed at the interface between the zirconia membrane and the slag, as shown typically in Fig. 7b. At a high slag basicity of 0.8 , some typical dendrite zirconia structures can be observed at the Ir electrode and the molten slag/zirconia membrane interface, as shown in Figs. 6 and 7d, respectively. Especially, a disaggregated zone of the zirconia membrane is formed in the molten slag and expands from the molten slag/zirconia membrane interface to the interior of the membrane. The distinction of the corrosion of zirconia membranes among different slag basicities is ascribed to a combination of two primary corrosion mechanisms. The first is increased penetration of the slag to the zirconia membrane due to the lower viscosity of high-basicity slag. Existing data on the viscosities of slags suggest that the slag with a high basicity of 0.8 has the lowest viscosity of the three used in the present work [42]. This reduced viscosity leads to increased penetration along grain boundaries and pores, and the resultant working loose of the grains from the molten slag/zirconia interface to the interior of the membrane. In contrast, the penetration of the slag with low basicity was significantly reduced. The second is the chemical attack. The calculation using FactSage [24] shows that the solubility of zirconia in the initial $\mathrm{SiO}_{2}-\mathrm{CaO}-\mathrm{MgO}-\mathrm{Al}_{2} \mathrm{O}_{3}-\mathrm{FeO}$ molten slag phase is relatively small in the present work and varies only from 1.5 to $2.3 \mathrm{wt} \%$ with an increase in slag basicity from 0.4 to 0.8 . The zirconia is readily soluble in more basic slag. The low solubility of zirconia in slag phase leads to precipitation of the partial dissolved zirconia in the form of dendrite crystals at other sites. The observed irregular shapes with a serrated border and dendrite structures suggest the corrosion of zirconia grains occurred by chemical dissolution. That the dendrite zirconia structures cannot be observed in the molten slag with low basicity may be ascribed to a slower dissolution rate of the zirconia due to the larger viscosity of low-basicity slag. Since the zirconia grains at the molten slag/zirconia membrane interface are soluble directly in the slag with high basicity, chemical attack may continue to destroy the zirconia membrane. The above two primary corrosion mechanisms result in disaggregation of the zirconia membrane in the molten slag with a high basicity of 0.8 under applying voltage.

It should be noticed that no interfacial product is found at the interface between the zirconia membrane and the molten slag. This is important for maintaining the motion of oxygen ions during electrolysis with COF.

It is well known that the molten slags containing $\mathrm{FeO}$ exhibit a certain electronic conductivity [34, 43]. It is inferred that slag penetration into the zirconia membrane and the phase transformation with an increase of the monoclinic phase amount can induce an increase of electronic conductivity of the zirconia membrane. Thus the external current is actually the sum of the pure oxygen ionic current and the internal electronic current passing directly through the zirconia membrane. Obviously, the external current is greater than the pure oxygen ionic current, and this is another reason why the final reduction ratios of $\mathrm{FeO}$ calculated by Eq. (14) are excessively high, as shown in Fig. 5. It should be noted that the internal electronic current could not be measured directly in real time and does not have the reduction function yet.

At high slag basicity $(R=0.8)$, the disaggregation of the zirconia membrane, as well as zirconia grain, and the crystalline structure in large amount, is observed in the residue when compared with other basicities as shown in Fig. 7d, indicating severe corrosion of the zirconia membrane by molten slag. However, the integrity of the zirconia microstructure can be held on the whole with the slag basicity not exceeding 0.6 , indicating smaller corrosion degree of the zirconia membrane. It is well known that there is great difficulty in obtaining an absolute inert anode in the molten slag at high temperatures $[5,6]$. Therefore, it is considered acceptable in a certain extent that the zirconia membrane serves an oxygen-producing and relatively noncorrosive anode material in the molten slag with lower basicity in electrolysis process with COF. In view of the larger conductivity of the slag with a basicity of 0.6 than with a basicity of 0.4 , the slag basicity value of 0.6 is relatively advisable in order to extract iron and minimize the corrosion of the molten slag to the zirconia membrane. Of course, it should be noted that the zirconia phase transformation caused by the molten slag not only leads to a gradual degradation of the membrane, but also decreases process efficiency, which is adverse to electrolysis.

\section{Conclusions}

(1) The decomposition voltage of the $\mathrm{FeO}$ in $\mathrm{SiO}_{2}-$ $\mathrm{CaO}-\mathrm{MgO}-\mathrm{Al}_{2} \mathrm{O}_{3}$ molten slag was measured using the constructed electrolytic cell with $\mathrm{COF}$ by the 
linear sweep voltammetry at $1723 \mathrm{~K}$. Higher slag basicity and cathode alloying are favorable to the $\mathrm{FeO}$ electrolytic reduction.

(2) With the iridium wire used as the cathode and an applied voltage of $2.5 \mathrm{~V}$, higher slag basicity leads to higher reaction rate and higher reduction ratio of the FeO. However, silicon is also precipitated during electroreduction, which may produce $\mathrm{Si}-\mathrm{Fe}-\mathrm{Ir}$ alloy with low melting point and result in the damage of the Ir electrode.

(3) The applied voltage can cause the increased porosity in the zirconia membrane. The higher slag basicity also has a strong impact on the corrosion of the zirconia membrane by the molten slag during electrolysis. It is considered acceptable that the zirconia membrane serves an oxygen-producing and relatively noncorrosive anode material in the molten slag with lower basicity in electrolysis process with COF.

(4) In order to extract iron and minimize the corrosion of the molten slag to the zirconia membrane under the conditions of experimentation, the slag basicity of 0.6 is relatively advisable.

Acknowledgments The authors acknowledge the project funds provided by the National Natural Science Foundation of China (No. 51174148).

\section{References}

1. Tian Y, Zhu Q, Geng Y (2013) An analysis of energy-related greenhouse gas emissions in the Chinese iron and steel industry. Energy Policy 56:352-361

2. Xu C, Cang D (2010) A brief overview of low $\mathrm{CO}_{2}$ emission technologies for iron and steel making. J Iron Steel Res Int 17:1-7

3. Wang D, Gmitter A, Sadoway D (2011) Production of oxygen gas and liquid metal by electrochemical decomposition of molten iron oxide. J Electrochem Soc 158:E51-E54

4. Kim H, Paramore J, Allanore A, Sadoway D (2011) Electrolysis of molten iron oxide with an iridium anode: the role of electrolyte basicity. J Electrochem Soc 158:E101-E105

5. Allanore A, Yin L, Sadoway D (2013) A new anode material for oxygen evolution in molten oxide electrolysis. Nature 497:353-356

6. Allanore A (2015) Features and challenges of molten oxide electrolytes for metal extraction. J Electrochem Soc 162:E13E22

7. Sirk A, Sadoway D, Sibille L (2010) Direct electrolysis of molten lunar regolith for the production of oxygen and metals on the moon. ECS Trans 28:367-373

8. Allanore A (2013) Electrochemical engineering of anodic oxygen evolution in molten oxides. Electrochim Acta 110:587-592

9. Gao Y, Jiang Y, Zhang H, Guo X, Chou K (2007) Metallurgy with controlled oxygen flow. J Wuhan Univ Technol 30:449-453

10. Pal U, Powell A (2007) The use of solid-oxide-membrane technology for electrometallurgy. JOM 59(5):44-49
11. Krishnan A, Pal U, Lu X (2005) Solid oxide membrane process for magnesium production directly from magnesium oxide. Metall Mater Trans B 36:463-473

12. Britten S, Pal U (2000) Solid-state amperometric sensor for the in situ monitoring of slag composition and transport properties. Metall Mater Trans B 31:733-753

13. Gratz E, Guan X, Milshtein J, Pal U, Powell A (2014) Mitigating electronic current in molten flux for the magnesium SOM process. Metall Mater Trans B 45:1325-1336

14. Milshtein J, Gratz E, Pati S, Powell A, Pal U (2013) Yttria stabilized zirconia membrane stability in molten fluoride fluxes for low-carbon magnesium production by the SOM process. J Min Metall B 49:183-190

15. Guan X, Pal U, Powell A (2014) Energy-efficient and environmentally friendly solid oxide membrane electrolysis process for magnesium oxide reduction: experiment and modeling. Metall Mater Trans E 1:132-144

16. Martin A, Poignet J, Fouletier J, Allibert M, Lambertin D, Bourgès $G$ (2010) Yttria-stabilized zirconia as membrane material for electrolytic deoxidation of $\mathrm{CaO}-\mathrm{CaCl}_{2}$ melts. J Appl Electrochem 40:533-542

17. Lu X, Zou X, Li C, Zhong Q, Ding W, Zhou Z (2012) Green electrochemical process solid-oxide oxygen-ion-conducting membrane (SOM): direct extraction of Ti-Fe alloys from natural ilmenite. Metall Mater Trans B 43:503-512

18. Gao Y, Wang B, Wang S, Peng S (2013) Study on electrolytic reduction with controlled oxygen flow for iron from molten oxide slag containing FeO. J Min Metall B 49:49-55

19. Wang C (2000) Solid Electrolyte and Chemical Sensors. Metallurgical Industry Press, Beijing

20. Ogura T, Fujiwara R, Mochizuki R, Kawamoto Y, Oishi T, Iwase M (1992) Activity determinator for the automatic measurements of the chemical potentials of $\mathrm{FeO}$ in metallurgical slags. Metall Trans B 23:459-466

21. Van Wijingaarden MJUT, Dippenaar RJ (1986) The use of zirconia-based solid electrolytes for the rapid determination of iron oxide activities in iron- and steel-making slags. J S Afr Inst Min Metall 86:443-453

22. Turkdogan E (2000) Theoretical concept on slag-oxygen sensors to measure oxide activities related to $\mathrm{FeO}, \mathrm{SiO}_{2}$, and $\mathrm{CaO}$ contents of steelmaking slags. Ironmak Steelmak 27:32-36

23. Franks E (1977) Electroanalysis of iron in molten slags. J Appl Electrochem 7:147-151

24. Bale C, Bélisle E, Chartrand P, Decterov S, Eriksson G, Hack K, Jung I, Kang Y, Melançon J, Pelton A, Robelin C, Petersen S (2009) FactSage thermochemical software and databases: recent developments. Calphad 33:295-311

25. Okamoto H (2007) Ir-Si (Iridium-Silicon). J Phase Equilib Diff 28:495

26. Gerlach S, Claußen O, Rüssel C (1999) A voltammetric study on the thermodynamics of the $\mathrm{Fe}^{3+} / \mathrm{Fe}^{2+}$ equilibrium in alkali-limealumosilicate melts. J Non-Cryst Solids 248:92-98

27. Schreiber H, Coolbaugh M (1995) Solvations of redox ions in glass-forming silicate melts. J Non-Cryst Solids 181:225-230

28. Sugawara T, Fujita Y, Kato M, Yoshida S, Matsuoka J, Miura Y (2009) Evaluation of voltammetric redox potential for $\mathrm{Fe}^{3+} / \mathrm{Fe}^{2+}$ in silicate liquids. J Ceram Soc Jpn 117:1317-1323

29. Dolan M, Johnston R (2004) Multicomponent diffusion in molten slags. Metall Mater Trans B 35:677-684

30. Min D, Fruehan R (1992) Rate of reduction of FeO in slag by FeC drops. Metall Mater Trans B 23:29-37

31. Swartzendruber L (1984) The Fe-Ir (Iron-Iridium) system. Bull Alloy Phase Diagrams 5:48-52

32. Yu J, Yi W, Chen B, Chen H (1987) Binary alloy phase diagrams. Shanghai Science and Technology Press, Shanghai, p 235 
33. Huang XH (2013) Metallurgical principles in ironmaking and steelmaking, $4^{\text {th }}$ Edn. Metallurgical Industry Press, Beijing, pp 288-300

34. Barati M, Coley KS (2006) Electrical and electronic conductivity of $\mathrm{CaO}-\mathrm{SiO}_{2}-\mathrm{FeO}_{\mathrm{x}}$ slags at various oxygen potentials: part $\mathrm{I}$. Experimental results. Metall Mater Trans B 37:41-49

35. Verein Deutscher Eisenhuttenleute (1995) Slag atlas, 2nd edn. Verlag Stahleisen GmbH, Düsseldorf, pp 21-403

36. Chung Y, Schlesinger M (1994) Interaction of $\mathrm{CaO}-\mathrm{FeO}-\mathrm{SiO}_{2}$ slag with partially stabilized zirconia. J Am Ceram Soc 77:611-616

37. Aneziris C, Pfaff E, Maier H (2000) Corrosion mechanism of low porosity $\mathrm{ZrO}_{2}$ based materials during near net shape steel casting. J Eur Ceram Soc 20:159-168

38. Hemberger Y, Berthold C, Nickel K (2012) Wetting and corrosion of yttria stabilized zirconia by molten slags. J Eur Ceram Soc 32:2859-2866
39. Sauerbrey RK, Mori G, Majcenovic CH, Harmuth H (2009) Corrosion protection of $\mathrm{MgO}$ electrodes at $1400^{\circ} \mathrm{C}$. Corros Sci $51: 1-5$

40. Riaz S, Mills KC, Bain K (2002) Experimental examination of slag/refractory interface. Ironmak Steelmak 29:107-113

41. Monaghan BJ, Nightingale SA, Dong Q, Funcik M (2010) The effects of an applied voltage on the corrosion characteristics of dense $\mathrm{MgO}$. Engineering 2:496-501

42. Gao Y, Wang S, Hong C, Ma X, Yang F (2014) Effects of basicity and $\mathrm{MgO}$ content on the viscosity of $\mathrm{SiO}_{2}-\mathrm{CaO}-\mathrm{MgO}-$ $9 \mathrm{wt} \% \mathrm{Al}_{2} \mathrm{O}_{3}$ slag system. Int J Min Met Mater 21:353-362

43. Barati M, Coley KS (2006) Electrical and electronic conductivity of $\mathrm{CaO}-\mathrm{SiO}_{2}-\mathrm{FeO}_{\mathrm{x}}$ slags at various oxygen potentials: part II. Mechanism and a model of electronic conduction. Metall Mater Trans B 37:51-60 